\title{
Mapping hazards from glacier lake outburst floods based on modelling of process cascades at Lake 513, Carhuaz, Peru
}

\author{
D. Schneider ${ }^{1}$, C. Huggel ${ }^{1}$, A. Cochachin ${ }^{2}$, S. Guillén ${ }^{3}$, and J. García ${ }^{4}$ \\ ${ }^{1}$ Department of Geography, University of Zurich, Zurich, Switzerland \\ ${ }^{2}$ Unidad de Glaciología y Recursos Hídricos, Autoridad Nacional de Agua, Huaraz, Peru \\ ${ }^{3}$ Laboratoire de constructions hydrauliques, EPFL, Lausanne, Switzerland \\ ${ }^{4}$ CREALP, Centre de recherche sur l'environnement alpin, Sion, Switzerland
}

Correspondence to: C. Huggel (christian.huggel@geo.uzh.ch)

Received: 8 February 2013 - Revised: 18 October 2013 - Accepted: 9 November 2013 - Published: 6 January 2014

\begin{abstract}
Recent warming has had enormous impacts on glaciers and high-mountain environments. Hazards have changed or new ones have emerged, including those from glacier lakes that form as glaciers retreat. The Andes of Peru have repeatedly been severely impacted by glacier lake outburst floods in the past. An important recent event occurred in the Cordillera Blanca in 2010 when an ice avalanche impacted a glacier lake and triggered an outburst flood that affected the downstream communities and city of Carhuaz. In this study we evaluate how such complex cascades of mass movement processes can be simulated coupling different physically-based numerical models. We furthermore develop an approach that allows us to elaborate corresponding hazard maps according to existing guidelines for debris flows and based on modelling results and field work.
\end{abstract}

\section{Introduction}

High-mountain environments with snow and ice are particularly sensitive to climatic changes (Haeberli and Beniston, 1998; Lemke et al., 2007). Rapid glacier retreat with formation of new lakes, degradation of permafrost with destabilizing effects on mountain slopes and critical changes in hydrological regimes and water supply are key challenges for local high-mountain communities and adjacent lowland regions (Moors et al., 2011; Voigt et al., 2011). Of special concern are cascading mass movement processes, e.g. rock or ice avalanches impacting glacier lakes and triggering glacier lake outburst floods (GLOF) with farreaching, highly destructive power. Such cascading processes have been observed at many sites around the world where they demonstrated their extraordinarily high hazard potential (Huggel et al., 2005; Kershaw et al., 2005; Petrakov et al., 2008; Schneider et al., 2011).

The Cordilleras in Peru (Fig. 1) are especially vulnerable to, and affected by, impacts from climate change (Carey, 2005; Bury et al., 2011). Local communities and cities often exist directly within the reach of major hazard potentials such as lake outburst floods (aluviones), mud-/debris flows (huaycos) or large rock-/ice avalanches. They have been repeatedly and severely affected during the last decades to centuries and thousands of people have been killed (Plafker and Ericksen, 1978; Ames, 1998; Carey, 2005; Evans et al., 2009; Carey et al., 2012). One reason for people living in the vicinity of icy mountain peaks and thus in potentially hazardous zones is their strong dependence on water resources from glacier melt because of the pronounced dry season ( $\sim$ May to September) in this geographic region (Baraer et al., 2012). People and institutions of the Cordilleras in Peru, and in the Cordillera Blanca in particular, have long-standing experience with living and adapting to changing environmental conditions (Carey, 2005; Carey et al., 2012). As early as in the 1940s, for instance, risk reduction measures were undertaken at unstable glacier lakes (Lliboutry et al., 1977). However, current changes are rapidly evolving beyond historical experience and pose increasingly large challenges to local communities and institutions (Allen et al., 2009; Haeberli et al., 2010).

One of the most recent events in the Cordillera Blanca occurred on 11 April 2010, when an ice-rock avalanche from the top of Hualcán mountain $\mathrm{NE}$ of the town of 


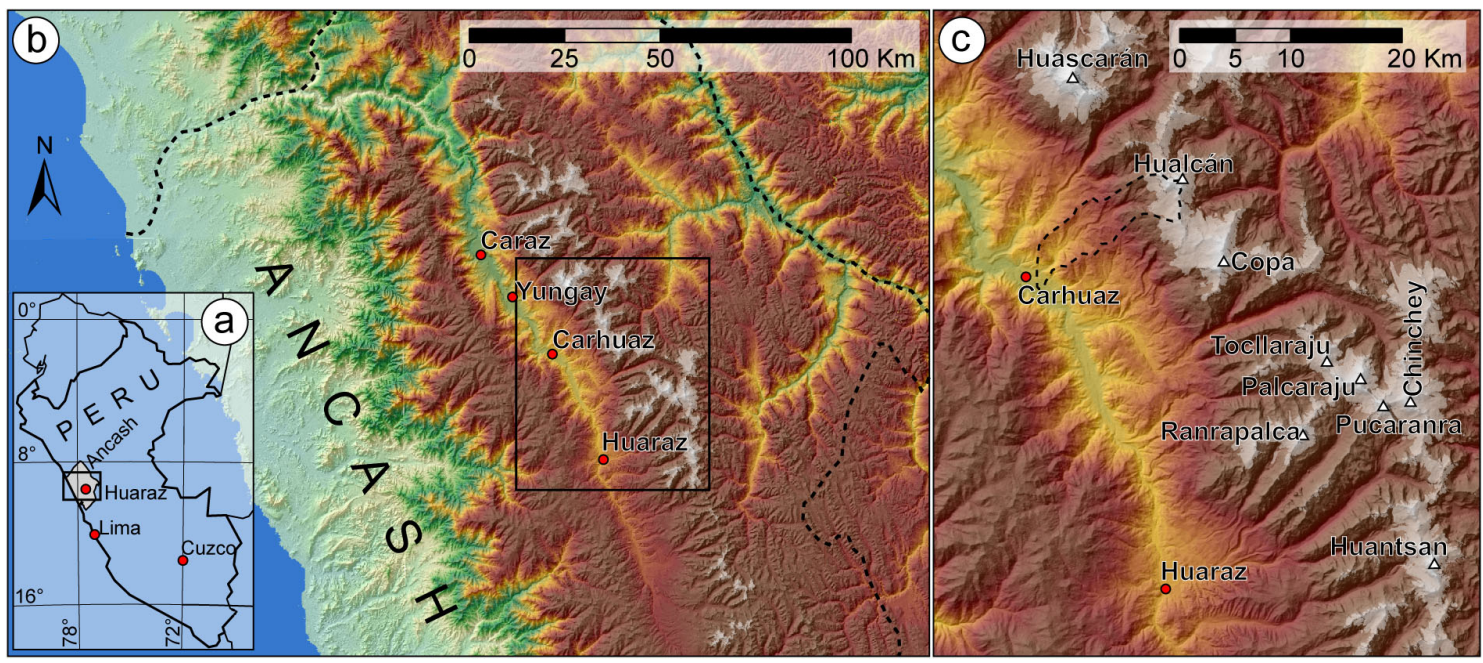

Fig. 1. (a) Location of province of Ancash (gray) in Peru. (b) Overview of the Cordillera Blanca (gray) within Ancash (dashed line). (c) Detail of the Cordillera Blanca with the cities of Huaraz and Carhuaz and the Río Chucchun river catchment as the main study site (dashed line). Gray areas indicate the glaciers in the year 2003 and the triangles show peaks $>6000 \mathrm{~m}$ a.s.l. and the corresponding names. Rectangles correspond to the extents of the sub-images and background image is a colored hillshade relief derived from ASTER GDEM2 data.

Carhuaz (Figs. 1 and 2) entered a glacier lake (Laguna 513, $4428 \mathrm{~m}$ a.s.l., $\left.9^{\circ} 12^{\prime} 50^{\prime \prime} \mathrm{N}, 77^{\circ} 33^{\prime} 10^{\prime \prime} \mathrm{W}\right)$ which has been formed during the past few decades. The avalanche triggered a flood wave that transformed into a debris flow and impacted downstream areas as it reached the city of Carhuaz (Figs. 2 and 3) (Carey et al., 2012). Fortunately, nobody was seriously injured but damage to property was considerable. The rapidly changing geomorphologic and glaciological situation in the Cordillera Blanca in general, and more specifically at Hualcán mountain, can result in new critical hazard situations which need to be analyzed in more detail. Therefore, an integrated hazard assessment, including a detailed study of the current hazard situation and possible future scenarios as well as measures to improve local knowledge, capacities and concrete un-bureaucratic adaptation, are critically required.

Numerical simulations of mass movements such as avalanches and debris flows have been increasingly applied over the past years (Worni et al., 2013). A number of empirical or more physically based models are available and have been typically used to simulate single processes of high-mountain mass movements, including rock and ice avalanches (e.g. Schneider et al., 2010; Sosio et al., 2008), debris flows (e.g. Hürlimann et al., 2006; Huggel et al., 2008), or GLOFs (e.g. Osti and Egashira, 2008; Worni et al., 2012a). Limited experience, however, exist how to model complex coupled processes of downstream cascading mass movements, such as occurred in the case of the 2010 Lake 513 event. Here we first present results of a modelling study of this event, using a physically based mass movement model (RAMMS) for ice avalanche, and lake outburst flood and debris flow, and a hydrodynamic model (IBER) for the simulation of the impact wave in the lake and dam overtopping. These models were selected because they have been thoroughly tested in many case studies and settings, and because their input data requirements and generated output allowed us to couple them for the purpose of this study. Furthermore, they are open access for scientific studies. Based on the calibration and validation of the models with the 2010 event we develop different hazard scenarios for the purpose of generating a hazard map for the town of Carhuaz using results from modelling and field work.

\section{Data, study area and 2010 GLOF event}

For this study we used remote sensing imagery and digital elevation data: SPOT 5 multispectral images from 2006 as well as high-resolution imagery available from Google Earth dating from 2003. A digital elevation model (DEM) of $8 \mathrm{~m}$ resolution was derived from spring 2012 WorldView satellite images. Furthermore, field campaigns to collect bathymetric data from Lake 513 were undertaken in July 2007 and June 2011 (Cochachin et al., 2011). The bathymetric studies allowed to reconstruct geometry and volume of the glacier lake. Additional field work, such as GPS measurements and grain size analysis, was conducted along the lake outburst flood trajectory, from Lake 513 down to the deposits of the 2010 event in Carhuaz.

On 11 April 2010 at $\sim 08: 00 \mathrm{LT}$, a rock-ice avalanche detached from the southwest slope of Hualcán mountain at about $5400 \mathrm{~m}$ a.s.l. Carey et al. (2012) estimated the avalanche to have a failure volume between 200000 and $400000 \mathrm{~m}^{3}$. The volume estimation of Valderrama and Vilca (2010) is much higher with $1500000 \mathrm{~m}^{3}$. Based on photographic evidence Valderrama and Vilca (2010) suggest 

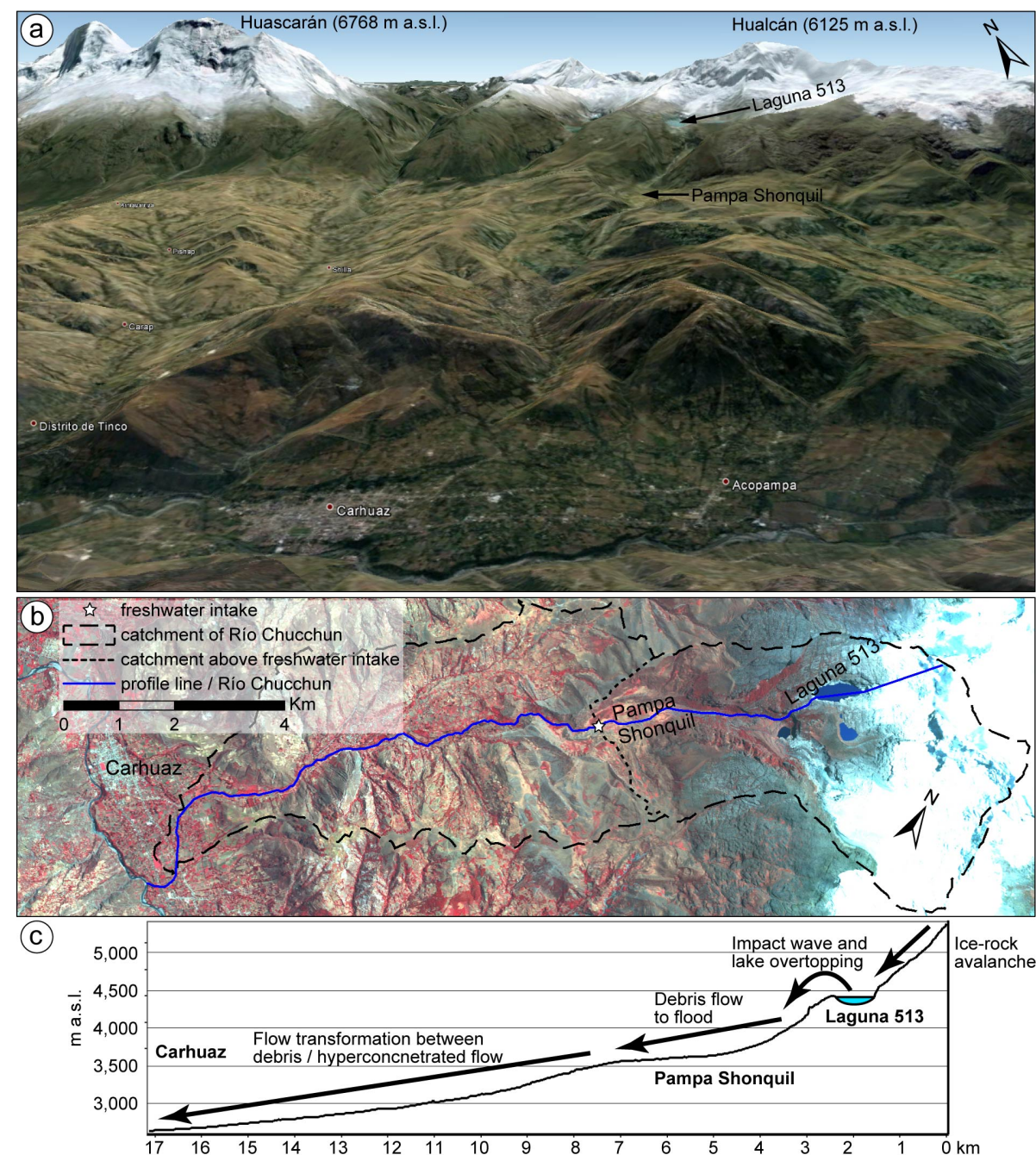

Fig. 2. Overview of the Río Chucchun catchment above the City of Carhuaz. (a) 3-D view from Google Earth, (b) SPOT satellite image from 2006 with the flow path (blue line) of the cascading mass movement processes and (c) the corresponding elevation profile.

that there has been at least a second avalanche of comparable size (in the order of $500000 \mathrm{~m}^{3}$ ) a few hours after the first event. This could also be an explanation for the different surges of the debris flow downstream, which have been reported by residents, but there remains some uncertainty regarding their timing and characteristics.

After crossing Glacier 513, the rock-ice avalanche hit Laguna 513 and triggered an impact wave. Field evidence showed that the wave overtopped the bedrock dam by about $5 \mathrm{~m}$ in height at a width of $20-25 \mathrm{~m}$. Taking into account the freeboard of $19 \mathrm{~m}$ the height of the overtopping wave was $24 \mathrm{~m}$. In 1993/1994 the level of Laguna 513 was artificially and permanently lowered by the construction of drainage tunnels through the bedrock dam. The analysis of the 2010 event indicated that without the tunnel constructions in 1993/94, the water level of Laguna 513 would have been higher and the volume and peak discharges of the flood wave in 2010 would have been easily one magnitude larger or more. Also a slightly larger avalanche and consequent impact wave at Laguna 513 might have led to a much larger volume of water spilling over the dam crest. Nevertheless, the relatively small amount of water which overtopped the dam in 2010 formed a debris flow with a complex multi-flow behavior.

For the 2010 event, five main stages have been identified (see also Fig. 4):

i. Slab failure type ice-rock avalanche from the steep flank of Nevado Huascarán running down towards Laguna 513.

ii. Impact of the ice-rock avalanche into Laguna 513 with the formation of an impact wave overtopping the dam.

iii. Glacial lake outburst flood (GLOF) with formation of a debris flow by lateral erosion of debris and and sediment entrainment, and subsequent sediment deposition 


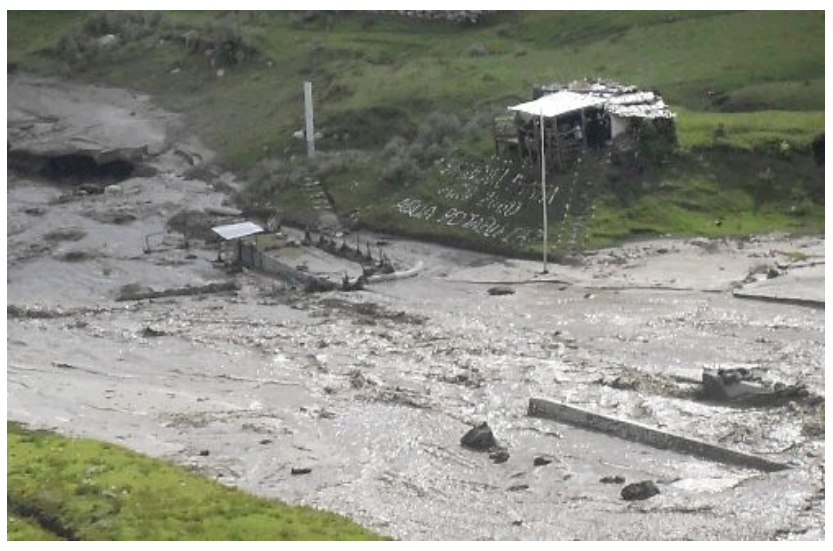

Fig. 3. Hyperconcentrated flow of 11 April 2010 at the site of the freshwater intake at Pampa Shonquil (3600 m a.s.1.). The structures have been completely inundated and partially damaged (mainly through erosion and deposition of material). Photo by Arq. Luis Meza, Carhuaz.

on the debris flow fan area above Pampa Shonquil. The GLOF in the upper Río Chucchún catchment was characterized by very high peak discharges, short total duration, high velocities and a very granular rheology consisting of a characteristic grain size in the range of 0.1-1 m (granodiorites) with a relative low concentration of fines.

iv. Hyperconcentrated flow (Fig. 3) with relatively slow drainage of the water and gravel-sand-silt fraction from the debris flow deposits in the upper Pampa Shonquil and flow propagation through the flat area of the Pampa. A hyperconcentrated flow is thereby defined as a flow of a water-sediment mixture with a sediment concentration of $20-60 \%$ by volume, while debris flows show higher sediment concentration of $60 \%$ or more (Worni et al., 2012b). We identified flow types based on field evidence of flow and sediment deposition, and channel geometry and characteristics. In the case of the 2010 event the flow density was increased by higher sediment concentration due to lateral erosion of the old sandy to silty lake sediments in the plain of Pampa Shonquil (Kaser and Osmaston, 2002).

v. Secondary debris flow initiation below Pampa Shonquil by increasing flow velocity due to a steeper flow channel and further erosion of friable material. At this stage, the peak discharge was much lower than at the time of the lake outburst flood, but the duration was longer. Coarse material was finally deposited within less inclined or wider zones in the channel and on the debris flow fan of Carhuaz while finer material reached Río Santa.

The 11 April 2010 event with its five main phases was the basis for the application of the models, and their calibration, as described in the next section. The dimension of the 2010 event also was taken into consideration for the development of the hazard scenarios.

\section{Modeling the 2010 avalanche and lake outburst flood}

The rock-ice avalanche of 11 April 2010 was modeled with the numerical and physically based avalanche and debris flow model "RAMMS" (Christen et al., 2010). This physically based dynamic model uses a finite-volume scheme to solve the 2-D shallow water equations. The frictional resistance in $x$ and $y$ direction which is acting against gravitational acceleration is described by using a Voellmy approach which incorporates a dry Coulomb friction $\mu$ and a turbulent friction $\xi$ (Bartelt et al., 1999). RAMMS has the advantage that maximum flow depths and maximum velocities are direct outputs for each cell of the DEM used. These two parameters are fundamental requirements for hazard mapping (see Sect. 4). Furthermore, RAMMS can be applied both for icerock avalanche and debris flow processes, and accordingly disposes of the option of block release or hydrograph mass movement initiation. This is an important advantage for modeling the cascading processes of Lake 513.

For the initial ice-rock avalanche the originally assumed $300000 \mathrm{~m}^{3}$ of ice and rock have been iteratively adjusted to fit the observations (flow traces, estimated source area volume) and to the spillover which was modeled in the next step. For the impact wave modeling in Laguna 513, the RAMMS model results have been used as input parameters. Particularly these have been the three parameters volume, density, and velocity of the avalanche at the time of the impact in Laguna 513. In Fig. 4 best-fits of the iterative retrospective modeling that led to impact velocities of the avalanche around $40-50 \mathrm{~m} \mathrm{~s}^{-1}$ on the lake surface can be seen.

Impact wave calculations were made using the method proposed by Heller et al. (2009). The input data for this method were volume, density and velocity of the mass incoming to the lake provided by RAMMS. To simulate the wave propagation along the lake, the IBER model (IBER, 2010) was used. IBER is a hydrodynamic model for simulating turbulent free surface unsteady flow and environmental processes in river hydraulics. It is based on a finite-volume non-structured mesh made up of triangle or quadrilateral elements. In the hydrodynamic module, the depth-averaged two-dimensional shallow water equations are solved (2-D Saint-Venant Equations) by an explicit upwind first-order scheme (Vázquez-Cendón, 1999), which performs well with irregular geometries such as high mountain topography. In addition, IBER has a friendly user interface that allows preprocessing, computation and post-processing without using additional software.

The input data for IBER was a hydrograph whose volume was estimated from the volume and density of the avalanche, as provided by RAMMS simulations. Peak discharge and 

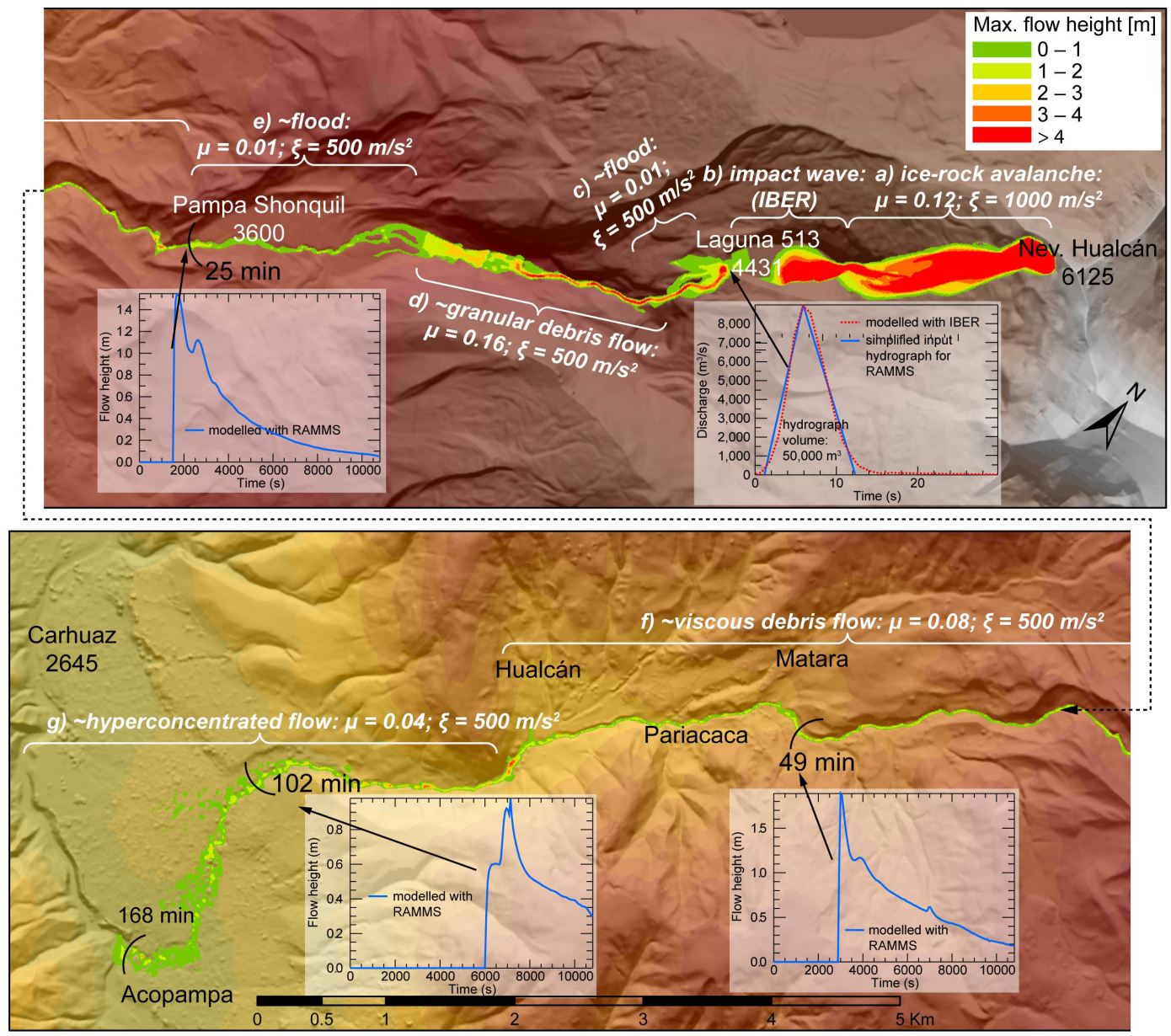

Fig. 4. Process chain of the 11 April 2010 event, modeled as follows: (a) rock-ice avalanche using RAMMS; (b) impact wave using IBER; and (c) to (g) flood to debris flow using RAMMS. The process cascade was initiated with an estimated ice-rock avalanche volume of $450000 \mathrm{~m}^{3}$. Parameters $\mu$ and $\xi$ correspond to the applied dry Coulomb and "turbulent"/viscous friction coefficient of the Voellmy model, respectively (Christen et al., 2010). Background: color-shaded relief of WorldView 8m-DEM.

its duration were adjusted in order to generate an initial wave similar to that calculated through Heller et al.'s (2009) method. Also, the back and forward swashing of the water as well as the spillover at the rock dam have been calibrated by the wave tracks visible in the post-event high resolution satellite image and examination during the field visit on 11 November 2011, suggesting a wave width of $\sim 22 \mathrm{~m}$ and maximum height of $\sim 5 \mathrm{~m}$ at the breach on the top of the dam. After the wave propagation, the results obtained by IBER (water depth, velocities and unitary discharges) were used to calculate the spillover hydrographs at the crest of the dam.

Modeling results indicate that for the estimated rock-ice avalanche density of $1000 \mathrm{~kg} \mathrm{~m}^{3}$ and the impact velocity calculated by RAMMS, a lake impact volume of at least $450000 \mathrm{~m}^{3}$ is required to produce a wave that overtops the dam. Such a volume does still fit in the range of the estimations described above, but it is evident that also the density and/or the velocity could have been higher than assumed and calculated to achieve the necessary impact momentum.

The spillover could be well represented by the IBER model simulations (Fig. 4), however, some modifications to the original assumptions were required so that the original impact volume of $300000 \mathrm{~m}^{3}$ has been augmented to 450000 $\mathrm{m}^{3}$ (see above).

Spillover hydrographs and water volumes calculated by IBER served as input for the following debris flow modeling with RAMMS. The calculations indicate extremely high peak discharges of $\sim 9000 \mathrm{~m}^{3} \mathrm{~s}^{-1}$ through the breach at the top of the dam with a quite short duration of the wave of $10 \mathrm{~s}$. This results in a calculated total spillover volume of only $\sim 50000 \mathrm{~m}^{3}$ for the 11 April 2010 event. IBER modeling results further suggest that there has not been a secondary or tertiary dam overtopping wave from forth- and back-swashing of the water because these waves must have been much smaller and most likely did not overtop the dam again. 
Table 1. Overview of volumes, peak discharges, and durations of the mass movement for each scenario and the applied models. Roman numbers correspond to the process stages described previously.

\begin{tabular}{|c|c|c|c|c|}
\hline & Scenario & (I) ice-rock avalanches & $\begin{array}{l}\text { (II) Flood wave over } \\
\text { dam of Laguna } 513 \\
\text { (start of GLOF) }\end{array}$ & $\begin{array}{l}\text { (III)-(V) flood/debris flow/ } \\
\text { hyperconcentrated flow } \\
\text { (ongoing process and } \\
\text { end of GLOF) }\end{array}$ \\
\hline Model & & RAMMS & IBER & RAMMS \\
\hline Volume & $\begin{array}{l}\text { small } \\
\text { medium } \\
\text { large }\end{array}$ & $\begin{array}{l}450000 \mathrm{~m}^{3} \\
1000000 \mathrm{~m}^{3} \\
3000000 \mathrm{~m}^{3}\end{array}$ & $\begin{array}{l}50000 \mathrm{~m}^{3} \\
350000 \mathrm{~m}^{3} \\
2400000 \mathrm{~m}^{3}\end{array}$ & $\begin{array}{l}100000 \mathrm{~m}^{3} \\
700000 \mathrm{~m}^{3} \\
4800000 \mathrm{~m}^{3}\end{array}$ \\
\hline $\begin{array}{l}\text { Peak } \\
\text { discharge }\end{array}$ & $\begin{array}{l}\text { small } \\
\text { medium } \\
\text { large }\end{array}$ & $\begin{array}{l}\text { slab failure } \\
\text { slab failure } \\
\text { slab failure }\end{array}$ & $\begin{array}{l}9000 \mathrm{~m}^{3} \mathrm{~s}^{-1} \\
40000 \mathrm{~m}^{3} \mathrm{~s}^{-1} \\
180000 \mathrm{~m}^{3} \mathrm{~s}^{-1}\end{array}$ & $\begin{array}{l}\text { not calculated } \\
\text { not calculated } \\
\text { not calculated }\end{array}$ \\
\hline \multirow[t]{3}{*}{ Duration } & small & $\begin{array}{l}\text { L513 reached after } 60 \mathrm{~s} \text {; } \\
245 \mathrm{~s} \text { until }<5 \% \text { of mass moving }\end{array}$ & $\begin{array}{l}30-40 \mathrm{~s} \text { after the } \\
\text { avalanche impact }\end{array}$ & $\begin{array}{l}\text { Pampa Shonquil: } 25 \mathrm{~min} \\
\text { Upper fan area: } 102 \mathrm{~min} \\
\text { Rio Santa: } 168 \mathrm{~min}\end{array}$ \\
\hline & medium & $\begin{array}{l}\text { L513 reached after } 45 \mathrm{~s} \text {; } \\
125 \mathrm{~s} \text { until }<5 \% \text { of mass moving }\end{array}$ & $\begin{array}{l}25-40 \mathrm{~s} \text { after the } \\
\text { avalanche impact }\end{array}$ & $\begin{array}{l}\text { Pampa Shonquil: } 15 \mathrm{~min} \\
\text { Upper fan area: } 65 \mathrm{~min} \\
\text { Rio Santa: } 100 \mathrm{~min}\end{array}$ \\
\hline & large & $\begin{array}{l}\text { L513 reached after } 40 \mathrm{~s} \text {; } \\
120 \mathrm{~s} \text { until }<5 \% \text { of mass moving }\end{array}$ & $\begin{array}{l}20-40 \text { s after the } \\
\text { avalanche impact }\end{array}$ & $\begin{array}{l}\text { Pampa Shonquil: } 5 \mathrm{~min} \\
\text { Upper fan area: } 35 \mathrm{~min} \\
\text { Rio Santa: } 55 \mathrm{~min}\end{array}$ \\
\hline
\end{tabular}

Another result of the model is that $\sim 200 \mathrm{~m}$ further downstream (below the tunnel outlet), the peak discharge had already reduced to $\sim 5000 \mathrm{~m}^{3} \mathrm{~s}^{-1}$. This suggests a rapid attenuation of the wave due to a longitudinal distribution of the water.

The downstream propagation of the water wave and development of a debris flow and hyperconcentrated flow with varying flow rheologies was modeled with the RAMMS model according to Mergili et al. (2011), Scheuner et al. (2009), and Stricker (2010). The required information for the input volumes, peak discharges, and shapes of the hydrograph were reconstructed based on field evidence and further available qualitative event descriptions, such as from Carey et al. (2012), by geometric characteristics of the event footprint derived from post-event satellite imagery, and according to the IBER modeling results. This strategy allowed the reconstruction of the entire process chain. The flow rheology of the GLOF was varied by applying spatially variable Voellmy friction parameters $\mu$ and $\xi$ (Christen et al., 2010) depending on the estimated grain size distribution and water content. This has been completed section-wise and in a strongly simplified qualitative way (Fig. 4).

The calculated inundation areas, flow heights and travel times correspond well with the reality. However, on the flat fan area between Carhuaz and Acopampa, the inundation appears somewhat exaggerated in width. Besides difficulties in determining realistic friction parameters and volumes for the model, the source of this inaccuracy could also have its origin in the DEM.

\section{Hazard assessment and mapping}

The RAMMS model was again used to calculate different potential future scenarios for ice-rock avalanches and GLOFs (Table 1, Fig. 5). Scenarios always include some uncertainty because they are based on magnitude-frequency relations, which are difficult to be evaluated and can differ for any geographic region. On the one hand, smaller events are usually not reported at all or get lost in records within a few decades. Large events, on the other hand, occur less frequently and it is thus also difficult to place them into a magnitude-frequency relation. Here, we rely on widely applied hazard mapping guidelines developed in Switzerland (Raetzo et al., 2002) and adopted in other countries including the Andes region (PMA_GCA, 2007) where scenarios of three different dimensions (small, medium, large) are defined. According to these guidelines scenarios may also be expressed in return periods (in years) but we restrain here from doing so because there is no statistical basis of past events to assess return periods (such as is commonly practiced, for instance, for rainfall triggered floods). It is therefore inevitable that the definition of the scenario dimensions introduces some degree of subjectivity. Based on the analysis of the 2010 event and an earlier event in 1991 of similar size, as well as the conditions found at Laguna 513, we defined an avalanche impact volume of $450000 \mathrm{~m}^{3}$ for the initial process at stage I (cf. Sect. 2) for the small scenario. Medium and large scenarios were assumed to involve volumes larger by a factor of $2-3$, resulting in 1 and 3 million $\mathrm{m}^{3}$, respectively. This is 

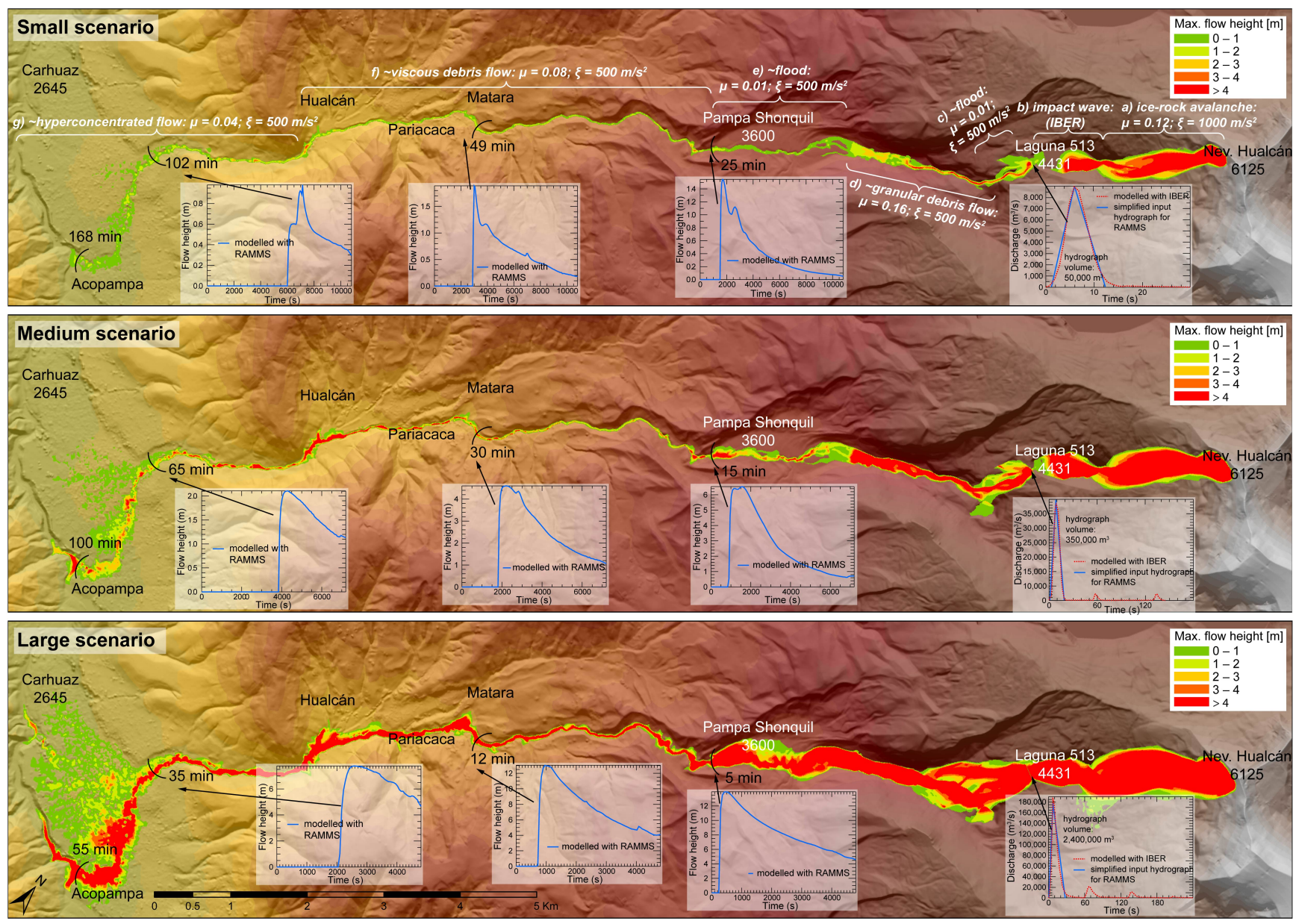

Fig. 5. Numerical modeling results (RAMMS) of three scenarios (small, medium, large) of potential mass movement process chains. The graph showing the small scenario includes indications of frictional parameters used in the RAMMS model which is valid for all three scenarios (white font). The dimensions of the ice-rock avalanche, dam overtopping flood wave, and flood, hyperconcentrated flow and debris flow for each scenario are given in Table 1. The three discharge hydrographs near the initiation area correspond to the output hydrograph calculated by the IBER model (red dotted line) and the simplified (blue) hydrograph has been used as input hydrograph for RAMMS. The three flow height hydrographs downstream have been calculated with RAMMS for a pixel at the center of the river. Note also the flow durations which are indicated in minutes along the flow path. Background: color-shaded relief of WorldView 8m-DEM.

realistic for the specific setting with a steep hanging glacier, and compared to other comparable avalanche initiation areas around the world (Schneider et al., 2011).

The volumes and peak discharges of the flood waves overtopping the dam of Laguna 513 are calculated with the IBER model based on the ice-rock avalanche input parameters as described above. The calculated flood wave volumes (Table 1) show that the retention function of the $20 \mathrm{~m}$ freeboard at Laguna 513 is limited to small-scenario avalanche impacts (comparable to the 2010 event) and that larger avalanches can mobilize water volumes close to the avalanche volume. Finally, the GLOF process (stages III-V) was modeled in a way that material was eroded by a factor of 2 compared to the initial volume. This erosion factor is based on an assumption of $50 \%$ debris content and could be adjusted. However, compared to other GLOF events around the world and an approximate debris content of $50 \%$ for debris flows, this value seems to be realistic.

Figure 5 shows the numerical modeling results of small, medium and large scenarios. While the rock-ice avalanches at stage (I) initiate as slab failures, the glacial lake outburst floods from Laguna 513 (III)-(V) require input flow hydrographs which are indicated in Fig. 5. Due to visibility reasons, only modeling results from RAMMS are shown and IBER results are not visible. Flow velocities were also calculated for the different scenarios but are not shown in Fig. 5. Potential lake outburst floods from the other existing and potential future lakes in this catchment were also analyzed. Results suggested that potential corresponding outburst floods would show similar behavior in the deposition zone and only differ in the upper area. Therefore they are not considered separately. 

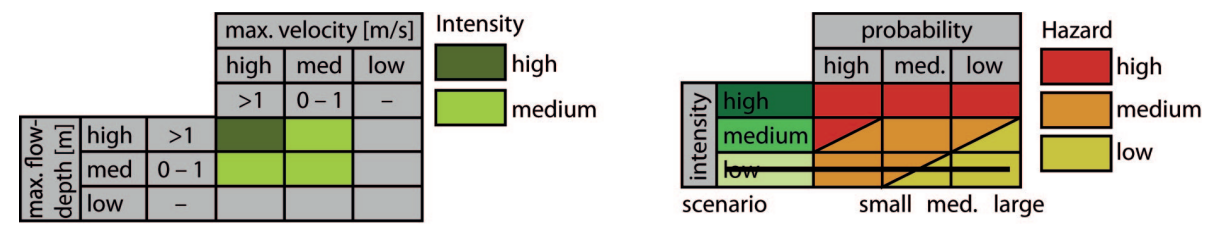

Fig. 6. Classification of debris flow intensities into two classes (left panel), and intensity-probability diagram and hazard levels (right panel) according to Raetzo et al. (2002). The low-intensity class does not exist for debris flows and is therefore marked as deleted (black line). For a better distinction of the different classes, orange is used instead of blue. See also Hürlimann et al. (2006).

The volumes increase for each flow stage due to entrainment of sediment, but peak discharges strongly reduce between stage (II) and (V) (hydrographs in Fig. 5). The RAMMS results also demonstrate that the modeled debris flows and floods (stages II to V) reach the upper fan area where deposition starts relatively fast, while the sedimentation of material on the entire fan takes much more time. In general, the chain processes need roughly about $30 / 60 / 90$ min from the initial ice-rock avalanche until the flood wave reaches the upper fan area near the city of Carhuaz for the small/medium/large scenario respectively. This time is of relevance for decision making within the alarm chain of an early warning system that is designed and implemented by several local, national and international institutions.

The RAMMS model is able to calculate maximum flow heights and maximum velocities of debris flow/hyperconcentrated flows for every scenario (Fig. 5). The schemes in Fig. 6 show how flow intensities are assessed as a function of flow velocity and flow height (according to guidelines by Raetzo et al., 2002). In a second step (right hand side of Fig. 6) flow intensities are converted into hazard levels. Following these schemes, we developed in this study a semi-automatic method implemented in a GIS environment that converts RAMMS-generated flow height and velocity cell-by-cell into intensities and hazard levels, similar to Hürlimann et al. (2006). According to the definition by Raetzo et al. (2002) there is no low intensity existing for debris flows. The threshold values and classification strategies by PMA_GCA (2007) and Hürlimann et al. (2006) which are slightly different from Raetzo et al. (2002) have also been applied, but the method by Raetzo et al. (2002) gave the most reliable results in this case. As indicated in Fig. 6, the intensities of each scenario (small, medium and large) are assigned to one of three hazard levels according to the intensity-probability diagram. Intensities and hazard levels were calculated and plotted separately for each scenario with given return period. The three scenario-based hazard maps were then combined into a single hazard map by choosing for each cell the highest hazard of the three previous hazard maps. The results are a sort of a raw product of a hazard map (Fig. 7, upper panel).

This raw product generated by numerical modeling served as a basis for field-based hazard mapping. Houses and smaller structures in the terrain are typically not well represented in a DEM and their effects are thus ignored by the numerical model. Hence, the modeling results need to be evaluated, verified and adapted in the field. Based on the field work, the raw product of the hazard map was generalized. Furthermore, two additional hazard levels were added (i.e. "very high" and "residual" hazards), as compared to indications by Raetzo et al. (2002). Integrating additional hazard levels was necessary in view of an earlier hazard map that existed for Carhuaz in order to ensure consistency in the communication with local authorities and administrative processes. The combined and generalized hazard map as the final product for the whole Chuchún catchment is shown in Fig. 7 (lower panel).

\section{Conclusions}

This study we included the following main components: (i) analysis of the 2010 ice-rock avalanche and lake outburst flood event at Lake 513; (ii) modelling the cascade of mass movement processes observed in 2010 using the numerical models RAMMS and IBER; (iii) definition of lake outburst flood scenarios, and corresponding modelling, considering the conceptual framework and requirements of hazard maps; and (iv) elaboration of a hazard map based on this modelling and field work.

Component (i) was important to understand the physical processes, and in particular, the coupling of those processes resulting in a cascade of mass movements and flood processes. It also supported selection of appropriate numerical models. The retrospective modelling of the 2010 event in component (ii) was necessary to calibrate the models and essentially couple RAMMS and IBER. Results and parameters from one model served as input into the other one, and many iterations were necessary to achieve a reasonable coupling of the models. Based on that, we proceeded to scenariobased modelling with the clear purpose of generating and updating the hazard map. Small, medium and large scenarios were defined according to existing guidelines, and initial avalanche volumes of 450000,1000000 and $3000000 \mathrm{~m}^{3}$ were defined, respectively. The results of the scenario-based model runs formed the basis for component (iv), the generation of a hazard map. Flow height and velocity per DEM 

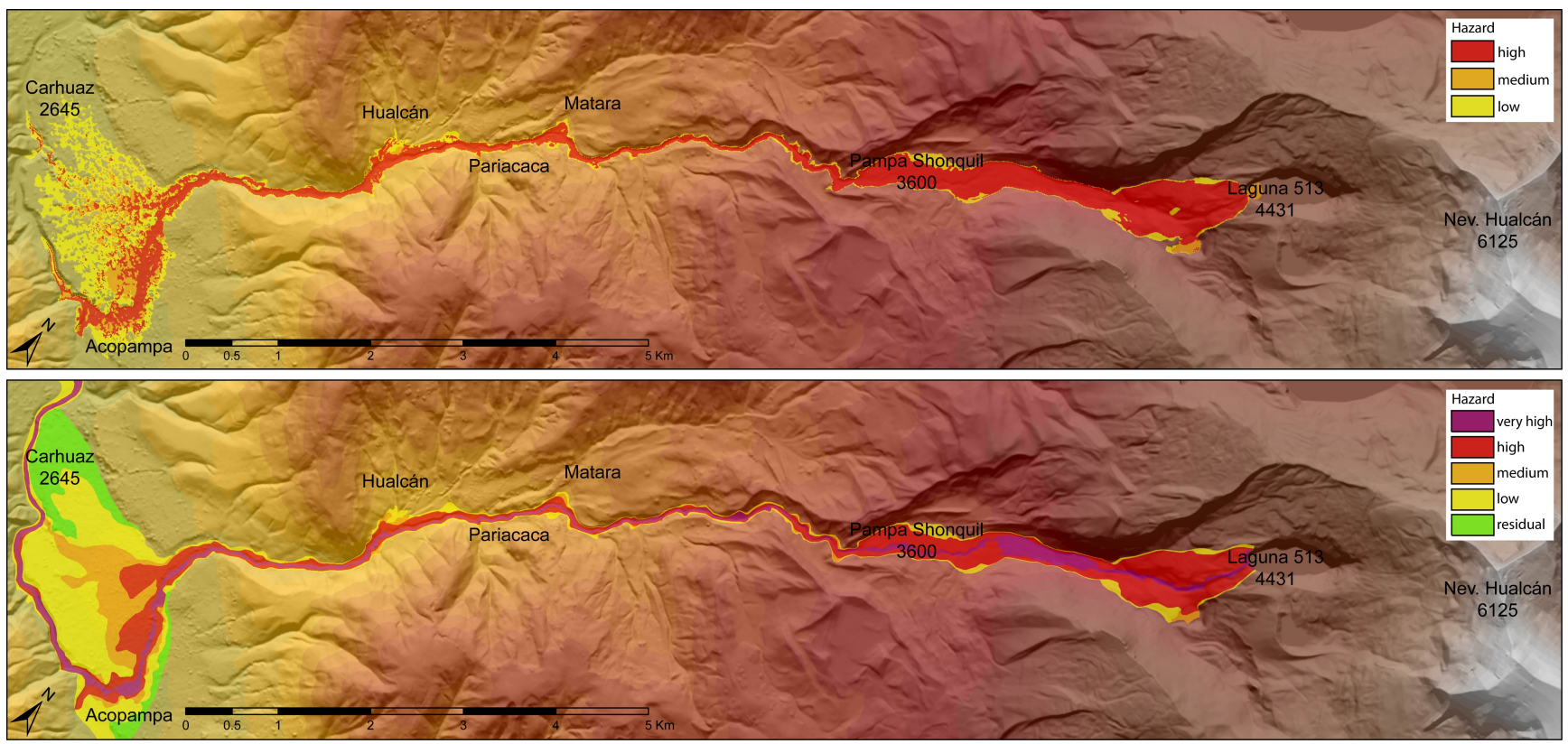

Fig. 7. Upper panel: raw form of hazard map derived from modeling results with RAMMS. In this map all three scenarios are included (for each cell, the highest hazard category according to the scheme in Fig. 6 is relevant). Lower panel: final hazard map representing a combined and generalized product of the raw product and field work. Background: color-shaded relief of the 8m-WorldView-DEM used for the numerical model.

cell were converted into different hazard levels, according to widely accepted guidelines and a GIS procedure. However, modelling results need to be verified in the field, especially at critical topographic sites which may imply model errors. Generation of hazard maps based solely on numerical modelling without additional field work is strongly discouraged.

In terms of the practical application of the results of this study it is noteworthy that the authorities of the city of Carhuaz recognize the hazard map produced in the framework of this study, and are using it among other for definition of evacuation routes in case of emergencies.

In terms of research we can state that modelling of complex cascades of mass movement processes is only at the beginning. This study shows that based on relatively well documented events coupling of physically based models is feasible and allows a realistic reproduction of corresponding events. More research, however, is needed to systematically investigate the influence of scenario definition, choice of model type and parameters on final inundation heights, flow velocities and other hazard parameters. Furthermore, although highly relevant for natural hazard practice as numerical mass movement models are increasingly applied now, there is little scientific guidance and reference how to structure the application of numerical models for the purpose of translating model results into hazard maps. This study can make a contribution in this respect but further documented cases would be desirable.
Acknowledgements. This study has been conducted within a Peruvian-Swiss climate change adaptation and risk reduction project ("Proyecto Glaciares"), funded by the Swiss Agency for Development and Cooperation (SDC). The project involves, and supports, collaboration between several Peruvian and Swiss scientific and technical institutions. We acknowledge the collaboration with CARE Peru, and especially with David Ocaña, Cesar González, Karen Price, and Lucas Torres and other colleagues at the Unidad de Glaciología y Recursos Hídricos, Autoridad Nacional de Agua, Huaraz. We also thank the following persons for various discussions and input: Cesar Portocarrero, Wilfried Haeberli, Claudia Giráldez, Yvonne Schaub, Holger Frey, Nadine Salzmann, Mario Rohrer, Toni Schleiss, and Jan Klimes. We furthermore acknowledge discussions on, and support of, the RAMMS model by colleagues from the WSL Institute for Snow and Avalanche Research (SLF, Marc Christen, Yves Bühler) and Brian McArdell (WSL). Finally, we greatly appreciate the comments made by Raphael Worni and another anonymous reviewer.

Edited by: K. Tokeshi

Reviewed by: R. W. Worni and two anonymous referees 


\section{References}

Allen, S. K., Schneider, D., and Owens, I. F.: First approaches towards modelling glacial hazards in the Mount Cook region of New Zealand's Southern Alps, Nat. Hazards Earth Syst. Sci., 9, 481-499, doi:10.5194/nhess-9-481-2009, 2009.

Ames, A.: A documentation of glacier tongue variations and lake development in the Cordillera Blanca, Peru, Z. Gletscherk. Glazialgeol., 34, 1-26, 1998.

Baraer, M., Mark, B. G., McKenzie, J. M., Condom, T., Bury, J., Huh, K.-I., Portocarrero, C., Gómez, J., and Rathay, S.: Glacier recession and water resources in Peru's Cordillera Blanca, J. Glaciol., 58, 134-150, 2012.

Bartelt, P., Salm, B., and Gruber, U.: Calculating dense snow avalanche runout using a Voellmy-fluid model with active/passive longitudinal straining, J. Glaciol., 45, 242-254, 1999.

Bury, J. T., Mark, B. G., McKenzie, J. M., French, A., Baraer, M., Huh, K. I., Zapata Luyo, M. A., and Gómez López, R. J.: Glacier recession and human vulnerability in the Yanamarey watershed of the cordillera Blanca, Peru, Climatic Change, 105, 179-206, 2011.

Carey, M.: Living and dying with glaciers: people's historical vulnerability to avalanches and outburst floods in Peru, Global Planet. Change, 47, 122-134, 2005.

Carey, M., Huggel, C., Bury, J., Portocarrero, C., and Haeberli, W.: An integrated socio-environmental framework for climate change adaptation and glacier hazard management: Lessons from Lake 513, Cordillera Blanca, Peru, Climatic Change, 112, 733767, 2012.

Christen, M., Kowalski, J., and Bartelt, P.: RAMMS: numerical simulation of dense snow avalanches in three-dimensional terrain, Cold Reg. Sci. Technol., 63, 1-14, 2010.

Cochachin, A.: Batimetría de la Laguna 513, Estudio y monitoreo de las lagunas altoandinas., Unidad de Glaciología y Recursos Hídricos, Autoridad Nacional del Perú, Huaraz, Peru, 2011.

Evans, S. G., Bishop, N. F., Smoll, L. F., Murillo, P. V., Delaney, K. B., and Oliver-Smith, A.: A re-examination of the mechanism and human impact of catastrophic mass flows originating on Nevado Huascarán, Cordillera Blanca, Peru in 1962 and 1970, Eng. Geol., 108, 96-118, doi:10.1016/j.enggeo.2009.06.020, 2009.

Haeberli, W. and Beniston, M.: Climate change and its impacts on glaciers and permafrost in the Alps, Ambio, 27, 258-265, 1998.

Haeberli, W., Clague, J. J., Huggel, C., and Kääb, A.: Hazards from lakes in high-mountain glacier and permafrost regions: climate change effects and process interactions, in Avances de la geomorfología en España 2008-2010, Proceedings XI Reunión Nacional de Geomorfología, Solsana, Spain., 2010.

Heller, V., Hager, W. H., and Minor, H.-E.: Landslide generated impulse waves in reservoirs - basics and computation, in: Mitteilungen, 211, edited by: Boes, R., ETH Zurich, Versuchsanstalt für Wasserbau, Hydrologie und Glaziologie (VAW), Zurich, 2009.

Huggel, C., Zgraggen-Oswald, S., Haeberli, W., Kääb, A., Polkvoj, A., Galushkin, I., and Evans, S. G.: The 2002 rock/ice avalanche at Kolka/Karmadon, Russian Caucasus: assessment of extraordinary avalanche formation and mobility, and application of QuickBird satellite imagery, Nat. Hazards Earth Syst. Sci., 5, 173-187, doi:10.5194/nhess-5-173-2005, 2005.
Huggel, C., Schneider, D., Miranda, P. J., Delgado Granados, H., and Kääb, A.: Evaluation of ASTER and SRTM DEM data for lahar modeling: A case study on lahars from Popocatépetl Volcano, Mexico, J. Volcanol. Geoth. Res., 170, 99-110, 2008.

Hürlimann, M., Copons, R., and Altimir, J.: Detailed debris flow hazard assessment in Andorra: a multidisciplinary approach, Geomorphology, 78, 359-372, 2006.

IBER: Two-dimensional modeling of free surface shallow water flow, Hydraulic reference manual, IBER v1.0., available at: http: //www.iberaula.es/web/index.php (last access: December 2013), 2010.

Kaser, G. and Osmaston, H.: Tropical glaciers, Cambridge University Press, Cambridge, 2002.

Kershaw, J. A., Clague, J. J., and Evans, S. G.: Geomorphic and sedimentological signature of a two-phase outburst flood from moraine-dammed Queen Bess Lake, British Columbia, Canada, Earth Surf. Proc. Land., 30, 1-25, 2005.

Lemke, P., Ren, J., Alley, R. B., Allison, I., Carrasco, J., Flato, G., Fujii, Y., Kaser, G., Mote, P., Thomas, R. H., and Zhang, T.: Observations: Changes in Snow, Ice and Frozen Ground, in Climate Change 2007: The Physical Science Basis, Contribution of Working Group I to the Fourth Assessment Report of the Intergovernmental Panel on Climate Change, edited by: Solomon, S., Qin, D., Manning, M., Chen, Z., Marquis, M., Averyt, K. B., Tignor, M., and Miller, H. L., Cambridge University Press, Cambridge, UK and New York, NY, USA, 337-383, 2007.

Lliboutry, L., Morales Arnao, B., Pautre, A., and Schneider, B.: Glaciological problems set by the control of dangerous lakes in Cordillera Blanca, Peru, J. Glaciol., 18, 239-290, 1977.

Mergili, M., Schneider, D., Worni, R., and Schneider, J. F.: Glacial lake outburst floods in the Pamir of Tajikistan: challenges in prediction and modeling, in: 5th International Conference on Debris-Flow Hazards Mitigation: Mechanics, Prediction and Assessment, 14-17 June, University of Padua, Italy, 973-982, 2011.

Moors, E. J., Groot, A., Biemans, H., van Scheltinga, C. T., Siderius, C., Stoffel, M., Huggel, C., Wiltshire, A., Mathison, C., Ridley, J., Jacob, D., Kumar, P., Bhadwal, S., Gosain, A., and Collins, D. N.: Adaptation to changing water resources in the Ganges basin, northern India, Environ. Sci. Policy, 14, 758-769, doi:16/j.envsci.2011.03.005, 2011.

Osti, R. and Egashira, S.: Hydrodynamic characteristics of the Tam Pokhari glacial lake outburst flood in the Mt. Everest region, Nepal, Hydrol. Process., 23, 2943-2955, 2009.

Petrakov, D. A., Chernomorets, S. S., Evans, S. G., and Tutubalina, O. V.: Catastrophic glacial multi-phase mass movements: a special type of glacial hazard, Adv. Geosci., 14, 211218, doi:10.5194/adgeo-14-211-2008, 2008.

Plafker, G. and Ericksen, G. E.: Nevados huascarán avalanches, Peru, Rockslides Avalanches, 1, 277-314, 1978.

PMA_GCA - Proyecto Multinacional Andino: Geociencias para las Comunidades Andinas: Movimientos en masa en la región andina: una guía para la evaluación de amenazas, Servicio Nacional de Geología y Minería, Publicación Geológica Multinacional, 4, Proyecto Multinacional Andino, Geociencias para las Comunidades Andinas, Canada, 2007.

Raetzo, H., Lateltin, O., Bollinger, D., and Tripet, J.: Hazard assessment in Switzerland - Codes of Practice for mass movements, Bull. Eng. Geol. Environ., 61, 263-268, doi:10.1007/s10064002-0163-4, 2002. 
Scheuner, T., Keusen, H. R., McArdell, B. W., and Huggel, C.: Murgangmodellierung mit dynamisch-physikalischem und GISbasiertem Fliessmodell, Wasser Energie Luft, 101, 15-21, 2009.

Schneider, D., Bartelt, P., Caplan-Auerbach, J., Christen, M., Huggel, C., and McArdell, B.: Insights into rock-ice avalanche dynamics by combined analysis of seismic recordings and a numerical avalanche model, J. Geophys. Res., 115, F04026, doi:10.1029/2010JF001734, 2010.

Schneider, D., Huggel, C., Haeberli, W., and Kaitna, R.: Unraveling driving factors for large rock-ice avalanche mobility, Earth Surf. Proc. Land., 36, 1948-1966, doi:10.1002/esp.2218, 2011.

Sosio, R., Crosta, G. B., and Hungr, O.: Complete dynamic modeling calibration for the Thurwieser rock avalanche (Italian Central Alps), Eng. Geol., 100, 11-26, 2008.

Stricker, B.: Murgänge im Torrente Riascio (TI): Ereignisanalyse, Auslösungsfaktoren und Simulation von Ereignissen mit RAMMS, Masterarbeit, Geographisches Institut, Universität Zürich, Zürich, 2010.

Valderrama, P. and Vilca, O.: Dinamica del aluvión de la Laguna 513, Cordillera Blanca, Ancash, Perú, Primeros alcances, in: XV Congreso Peruano de Geología, Resúmenes Extendidos, Volume Pub. Esp. No. 9, Sociedad Geológica del Perú, Cusco, Perú, 336-341, 2010.
Vázquez-Cendón, M. E.: Improved treatment of source terms in upwind schemes for the shallow water equations in channels with irregular geometry, Int. J. Comput. Phys., 199, 357-372, 1999.

Voigt, T., Füssel, H.-M., Gärtner-Roer, I., Huggel, C., Marty, C., and Zemp, M.: Impacts of climate change on snow, ice, and permafrost in Europe: Observed trends, future projections, and socio-economic relevance, European Environment Agency, Copenhagen, 2011.

Worni, R., Stoffel, M., Huggel, C., Volz, C., Casteller, A., and Luckman, B.: Analysis and dynamic modeling of a moraine failure and glacier lake outburst flood at Ventisquero Negro, Patagonian Andes (Argentina), J. Hydrol., 444-445, 134-145, 2012a.

Worni, R., Huggel, C., Stoffel, M., and Pulgarín, B.: Challenges of modeling current very large lahars at Nevado del Huila Volcano, Colombia, Bull. Volcanol., 74, 309-324, 2012 b.

Worni, R., Huggel, C., Dorren, L. K. A., and Jaboyedoff, M.: Numerical Modeling of Flows and Falls, in Treatise on Geomorphology, vol. 7, edited by: Shroder, J. F., Academic Press, San Diego, 273-283, 2013. 